\title{
Predictive Modeling of Biogas Production from Anaerobic Digestion of Mixed Kitchen Waste at Mesophilic Temperature
}

\author{
Aasim Ali ${ }^{1^{*}}$, Li Rundong ${ }^{2}$, Feroz Shah $^{3^{*}}$, RB Mahar ${ }^{1}$, Muhammad Wajidljaz ${ }^{4}$, Sallahuddin ${ }^{1}$ and Muhammad Muqueet ${ }^{1}$ \\ ${ }^{1}$ US-Pakistan Center for Advanced Studies-Water, Mehran University of Engineering \& Technology, Jamshoro, 76062, Sindh, Pakistan \\ ${ }^{2}$ Liaoning Provincial Key Laboratory of Clean Energy, Shenyang Aerospace University, China 110136 \\ ${ }^{3}$ Mehran University of Engineering \& Technology, Jamshoro, 76062, Sindh, Pakistan \\ ${ }^{4}$ Environmental Protection Agency, Lahore 54000, Pakistan
}

*Corresponding authors: Aasim Ali, US-Pakistan Center for Advanced Studies-Water, Mehran University of Engineering \& Technology, Jamshoro, 76062, Sindh, Pakistan, Tel: +09415695331; E-mail: Aasimali_69@yahoo.com

Feroz Shah, Mehran University of Engineering \& Technology, Jamshoro, 76062, Sindh, Pakistan, Tel: + 09415695331; E-mail: feroz.shah@faculty.muet.edu.pk

Received date: June 07, 2016; Accepted date: June 29, 2016; Published date: July 06, 2016

Copyright: ( 2016 Ali A, et al. This is an open-access article distributed under the terms of the Creative Commons Attribution License, which permits unrestricted use, distribution and reproduction in any medium, provided the original author and source are credited.

\begin{abstract}
Growth of population is directly influencing the municipal solid waste generation rate. Although, kitchen waste is disposed of mostly in developing countries and its potential of biogas production is not explored well. Anaerobic digestion provides opportunity of twofold benefits i.e. pollution abutment for environmental protection and biogas generation for sharing energy load. Present study was intended to understand the biogas production process at mesophilic temperature $\left(37^{\circ} \mathrm{C}\right)$. The organic waste from kitchen was used to make up substrate, which was anaerobically digested in an experimental continues stirred tank reactor (CSTR). Inhibition phase was detected when the graph was plotted for first 60 days and about 28th day it was inhabited. Biogas production from recovered condition was subjected to statistical analysis. Simple regression yielded a good predictive model that gave a correlation of 0.995 despite of including the inhibition phase in complete analysis. An acceptable agreement between observed and modeled biogas production (BGP) rates has vetted sanctity of regression based predictive model. Such models can also be used to keep check on digestion process for optimization of biogas yield and deciding the substrate feeding rate and concentration on time scale.
\end{abstract}

Keywords: Anaerobic digestion; Mixed kitchen waste; Biogas; CSTR; Statistical analysis, Biogas production

\section{Introduction}

A large fraction of municipal solid waste is biodegradable, in which kitchen waste constitutes $20-65 \%$ [1-3]. Kitchen waste provides more efficient method to produce biogas because it contains adequate amount of nutrients for the microbes [4]. In China, like other developing countries, large quantity of kitchen waste is generated in an ever-increasing magnitude with no commensurate, well-coordinated waste management programmes to meet up with the challenge. Concerns over air pollution and diminishing land availability are putting pressures on the now-widely-used practices of mass burning and land filling [5]. In past, the performance of a large number of landfills and incinerators have been quite poor, including landfills that were built with containment barrier (a clay liner or a synthetic membrane) [6]. Jain [7] identified some of the adverse environmental impacts of unscientific handling and indiscriminate dumping of solid waste. These include the following:

1. Ground water contamination by the leachates generated by the waste dumps.

2. Surface water contamination by the runoff from the waste dumps.

3. Foul odor, pests, rodents and windblown litter in and around the waste dumps.
4. Generation of inflammable gas (methane) within the waste dumps, resulting in fires at the landfill with smoke and smog around.

5. Release of green house gases such as carbon dioxide and methane

6. Bird menace above the waste dumps affecting air traffic.

7. Epidemics through stray animals and other diseases vectors.

Anaerobic biological treatment can be an acceptable solution because it reduces and stabilizes solid wastes volume and produces energy in terms of biogas. This biogas comprises mainly of methane and carbon dioxide and trace amounts of other gases [8]. It has been established that organic waste materials present in the mixed kitchen waste, such as vegetables contain adequate quantity of nutrients essential for the growth and metabolism of anaerobic bacteria in biogas production [9]. In addition to biogas, a nutrient-rich digestate is also produced, which can be used as organic fertilizer [10]. In future, it is believed that anaerobic digestion will be sought in perspective of an overall sustainable waste management [11]. Keeping in view, a laboratory-scale study was conducted to evaluate the potential of anaerobic digestion as a tool for managing mixed kitchen waste and a study was conducted by considering biogas production rate, (latterly BPR) at different Organic Loading Rates (latterly OLRs).

There are three main tendencies in anaerobic modeling for predicting the reactor behavior [12]. Based on kinetic equations such as Monod or Contois equation, an unstructured nonsegregated model $[13,14]$ and an unstructured segregated model [15] are proposed. The process inhabition due to sudden changes in organic loading rates, 
Citation: $\quad$ Ali A, Rundong L, Shah F, Mahar RB, Wajidljaz M, et al. (2016) Predictive Modeling of Biogas Production from Anaerobic Digestion of Mixed Kitchen Waste at Mesophilic Temperature. Int J Waste Resour 6: 230. doi:10.4172/2252-5211.1000230

Page 2 of 4

accumulation of volatile fatty acids and acidic conditions always marked the question mark on the stability of anaerobic digestion fermentation. Lots of research is going on to well understand the process and its influenced factors like $\mathrm{pH}$, temperature, food to microorganism, F/M ratio and mass balance specially in the case of CSTR. In this present study, simple regression approach was considered to predict the future validity of regression model. This model will help in designing the any anaerobic facility to treat efficiently organic waste by waiving the adaptation phase.

\section{Materials and Methods}

\section{Substrate collection and preparation}

The mixed kitchen waste segregated from inorganic material was used in this experiment. This waste was collected from Teachers' Dinning Hall at Shenyang Aerospace University, China. Nonbiodegradable components of mixed kitchen waste, such as bones and eggshells were removed prior to blending upto $4 \mathrm{~mm}$. The substrate was mixed with some water to enhance blending and homogeneity. The remaining amount of water was added later, as required. The prepared substrate was refrigerated at $4^{\circ} \mathrm{C}$. Physical characteristics of mixed kitchen waste are given as in Table 1.

\begin{tabular}{|l|l|l|l|l|}
\hline $\begin{array}{l}\text { Sr.N } \\
\mathbf{0}\end{array}$ & Parameter & $\begin{array}{l}\text { Present } \\
\text { Study }\end{array}$ & Vikrant [4] & $\begin{array}{l}\text { Zhang et al. } \\
\mathbf{( 2 0 0 7 )}\end{array}$ \\
\hline 1 & $\mathrm{p}^{\mathrm{H}}$ & 7.0 & $4-7.1$ & 7.57 \\
\hline 2 & COD(g/L) & - & $5-25$ & - \\
\hline 3 & TS(g/L) & 218.10 & $80-110$ & 309 \\
\hline 4 & TVS(g/L) & 202.83 & $68-93$ & 263 \\
\hline 5 & Moisture Content (\%) & 78.2 & $30-70$ & 70 \\
\hline
\end{tabular}

Table 1: Physical characteristics of mixed kitchen waste.

\section{Experimental setup}

The experimental design of anaerobic digestion of mixed kitchen waste was carried out in Continues Stirred Tank Reactor (CSTR). The reactor was operated at $37^{\circ} \mathrm{C}$ for 120 days. Anaerobic condition was ensured by flushing the $100 \%$ pure nitrogen for approximately 2 minutes [16]. An equal amount of water $(7 \mathrm{~L})$, mixed kitchen waste $(2$ $\mathrm{kg})$ and inoculum $(1 \mathrm{~kg})$ was added to digester. The whole process was set on fill and draw method everyday. The withdrawn digestate was used for the physico chemical analysis of the biodegradation of organic matters of kitchen waste.

\section{Analytical calculations}

Total Solids (TS), Volatile Solids (VS), Chemical Oxygen Demand (COD) and Total Ammonia Nitrogen (TNA) were analyzed according to standard methods [17]. The influence of $\mathrm{pH}$, temperature and loading rate on biogas yield and effectiveness of the process was observed and studied carefully. $\mathrm{pH}$ adjustment was done by 1 mole solution of $\mathrm{NaOH}$ [18] then monitored with a portable $\mathrm{pH}$ meter (HANNA Instruments, Italy). Volatile Fatty Acids (VFAs) were analysized by titration against $0.05 \mathrm{M} \mathrm{H}_{2} \mathrm{SO}_{4}$ to endpoints of $\mathrm{pH} 5.0$ and 4.4 [19]. Free Ammonia (FAN) concentration was calculated by using equation (1) [20].The volume of evolved biogas gas was measured with gas meter daily throughout the experiment [11]. The rotational speed of CSTR was 120 r.p.m.

\section{Statistical prediction}

It has been learned that $\mathrm{pH}, \mathrm{COD}$ loading and temperature play significant role in study of biogas production, that is why these parameters were opted for present study. In addition, this analysis attempts to establish the nature of the relationship between variables and thereby provides a mechanism for prediction or forecasting [21-23]. The analysis was composed of regression analysis of biogas production against given COD loading on retention time. A best fit model was derived from biogas production tendencies with 150 data points. First of all three potential phases of anaerobic digestion were studied through simple trend curves. After that regression technique was employed under following methodology:

$\mathrm{BGP}=\mathrm{mx}+\mathrm{c}$
Where:
$\mathrm{m}=$ Slop of trend line
$\mathrm{x}=$ Time in days
$\mathrm{c}=$ constant

However, r, correlation between observed and modeled values was measured with following equation:

\section{Results and Discussions}

\section{Phase detection}

BGP rate on daily basis was plotted for first 60 days. Figure 1, is showing recession limb (P2) in which BGP started decreasing from 28th day to onward with lag phase (P3) technically called inhibition phase due to toxicity. The uncertainty was going on continuously although substrate was being fed, as shown in Figure 2.

Natural complexities during anaerobic digestion enhance chances of inhibition / toxicity levels due to feeding of mixed substrate. Similarly antagonism, synergism and acclimation are biochemical factors those hit inhibition [24]. To deal this problem, an introduction was made in order to bring the situation to favorable conditions and by adding basic solution as discussed ago. The permissible $\mathrm{pH}$ was maintained and an improved BGP rate was detected as shown in Figure 3.

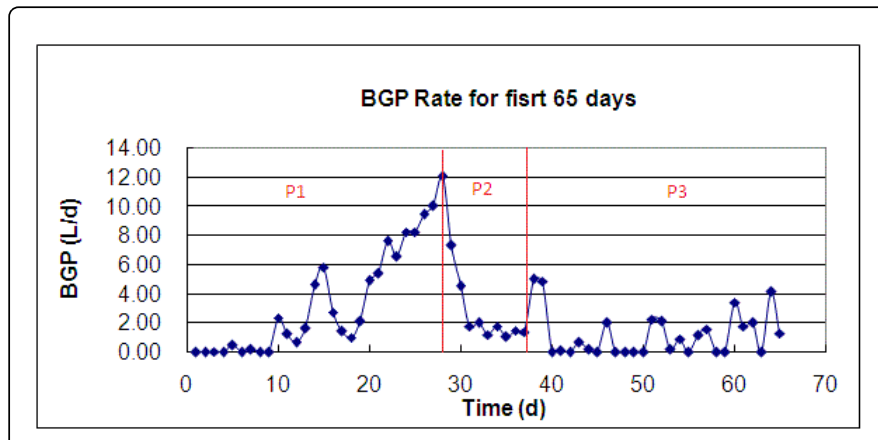

Figure 1: Variation in biogas production rate with respect to time. 
Citation: $\quad$ Ali A, Rundong L, Shah F, Mahar RB, Wajidljaz M, et al. (2016) Predictive Modeling of Biogas Production from Anaerobic Digestion of Mixed Kitchen Waste at Mesophilic Temperature. Int J Waste Resour 6: 230. doi:10.4172/2252-5211.1000230

Page 3 of 4

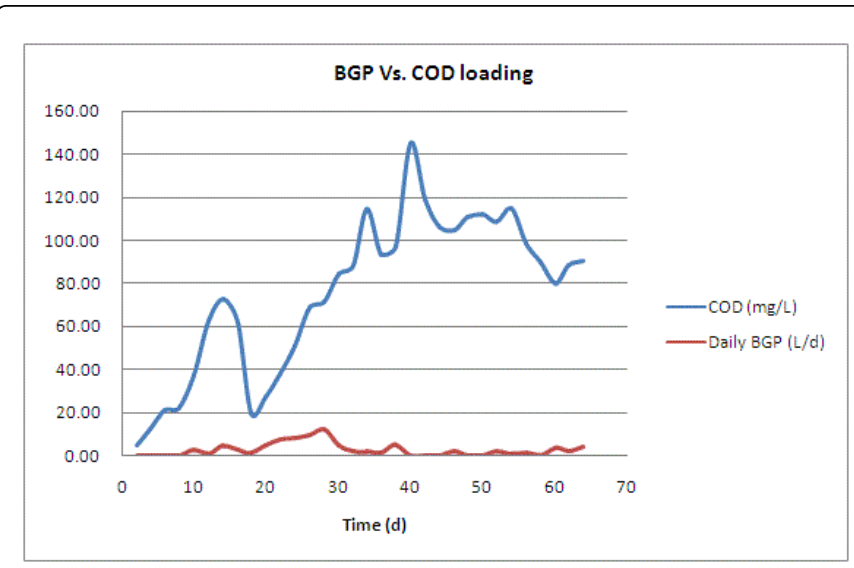

Figure 2: Trend of biogas production with respect to COD loading rate.

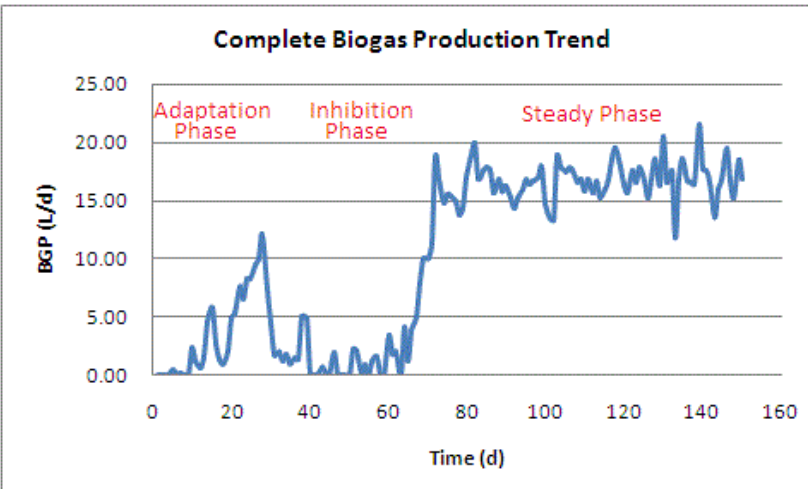

Figure 3: Modified trend of Biogas Production through external deliberation.

\section{Regression based predictive model}

As BGP rate started declining, trend analysis of adaptive phase (P1) provided an opportunity to rectify the toxic condition. After undertaking same, a consistent trend was observed that is called steady phase. Therefore, a linear regression based model was derived as following:

$\mathrm{BGP}=0.142 \mathrm{~T}-0.612$

Where, $\mathrm{T}$ is time in days.

Thus, Figure 4 Shows the uncertainty of model was tested through assessment of correlation between observed BGP and modeled values. For further elaboration of this phenomena, cumulative values were made up and it was observed that value of $r$ was 0.995 that indicated a good relation between both values. An acceptable agreement of modeled and observed values was present as depicted in Figure 5.

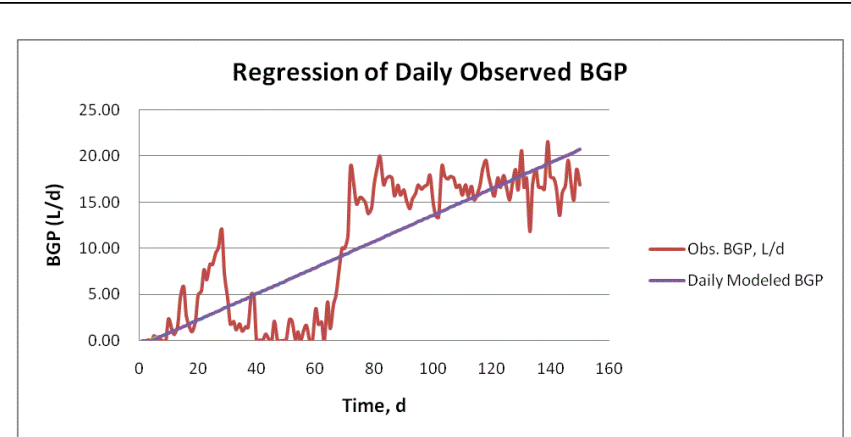

Figure 4: Linear regression based modeling of daily observed biogas production.

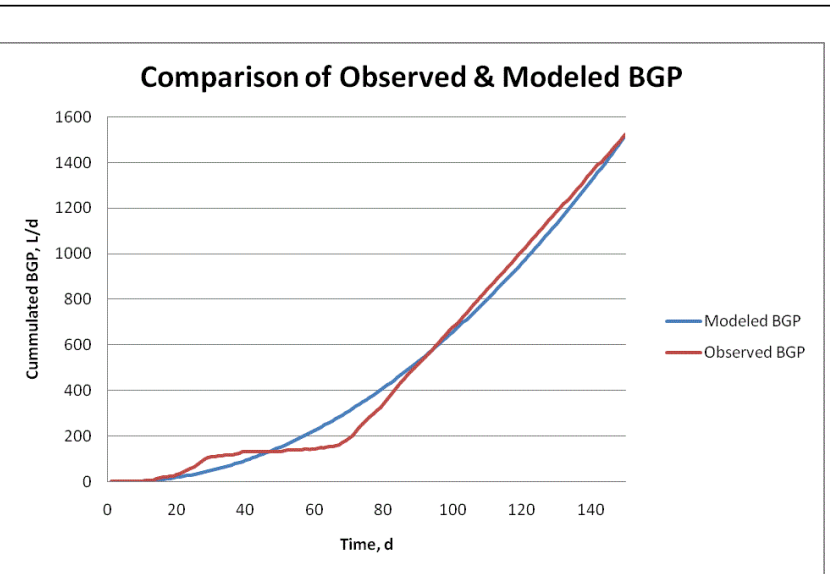

Figure 5: A curve fitting of observed and modeled biogas production.

\section{Conclusion}

Present experiment based study has revealed that anaerobic digestion of kitchen waste is not only one of the solid waste management technique but it could also be adopted as biogas production source. This study gives the different phase based analysis for the process fluctuation and varying conditions. For efficient use of anaerobic digestion, it is essential to pay deep attention to ensure favorable process conditions. Owing to statistical analysis, optimization of biogas production rate under anaerobic condition can be done. Consequently, it could be maintained that regression based linear model enables to predict biogas production under mesophilic conditions in anaerobic digestion of mixed kitchen waste with due confidence and it could also be used a process monitoring tool.

\section{Acknowledgment}

The authors are grateful to management of Shenyang Aerospace University, China for providing access to resources for accomplishment of this study especially Dr. Li Rundong who supervised the project and rendered valuable advices throughout the study. 
Citation: $\quad$ Ali A, Rundong L, Shah F, Mahar RB, Wajidljaz M, et al. (2016) Predictive Modeling of Biogas Production from Anaerobic Digestion of Mixed Kitchen Waste at Mesophilic Temperature. Int J Waste Resour 6: 230. doi:10.4172/2252-5211.1000230

Page 4 of 4

\section{References}

1. Tchobanoglous G, Theisen H, Vigil SA (1993) Integrated solid waste management. McGraw-Hill, Inc., New York.

2. Isaacson R, Pfeffer J, Mooij P, Geselbracht J (1987) RefCoM-Technical Status, Economics and Market, Presented at: Energy from biomass and wastes, XI, Orlando Florida.

3. De Baere L, van Meenen P, Deboosere S, Verstraete W (1987) Will anaerobic digestion of solid waste survive in the future?. Water Science and Technology 53: 187-194.

4. Vikrant D (2013) Generation of Biogas from Kitchen Waste Experimental Analysis. International Journal of Engineering Science Invention 2: 2319-6734.

5. Chynoweth DP, Legrand R (1988) Anaerobic digestion of municipal solid waste and sludge. Proceedings of the 23rd Intersociety Energy Conversion Engineering Conference (IECEC), Denver.

6. Giust L (2009) A review of waste management practices and their impact on human health. Waste Manag 29: 2227-2239.

7. Jain AK (2007) Sustainable development and waste development. International Society of Environmental Botanists.

8. Stroot PG, McMahon KD, Mackie RI, Raskin L (2001) Anaerobic codigestion of municipal solid waste and biosolids under various mixing conditions-I. Digester performance. Water Res 35: 1804-1816.

9. Bodkhe SY, Vaidya AN (2012) Complete recycle bioreactor for anaerobic digestion of organic substrates: Food waste. Research Journal of Chemistry and Environment.

10. Gunaseelan VN (1997) Anaerobic digestion of biomass for methane production: A review. Biomass and Bioenergy 13: 83-114.

11. Eldelmann W, Joss A, Engeli H (1999) Two step anaerobic digestion of organic solid wastes.

12. Garcia-Ocha F, Santos VE, Naval L, Guardiola E, Lopez B (1999) Kinetic model for anaerobic digestion of livestock manure. Enzyme and Microbial Technology 25: 55-60
13. Chen YR, Hashimoto AG (1980) Substrate utilization kinetic-model for biological treatment process. Biotechnology and Bioengineering 22: 2081-95.

14. Chen YR (1983) Kinetic analysis of anaerobic digestion of pig manure and its design implications. Agricultural Wastes 8: 65-81.

15. Hill DT (1983) Simplified Monod kinetics of methane fermentation of animal wastes. Agricultural Wastes 5: 1-16.

16. Kafle GK, Kim SH, Sung KL (2012) Ensiling of fish industry waste for biogas production: a lab scale evaluation of biochemical methane potential (BMP) and kinetics. Bioresources Technol 127: 326-336.

17. APHA (2005)

18. Xie S, Lawlor P, Frost J, Hu Z, Zhan X (2011) Effect of pig manure to grass silage ratio on methane production in batch anaerobic co-digestion of concentrated pig manure and grass silage. Bioresources Technol 102: 5728-5733.

19. Hansen KH, Angelidaki I, Ahring BK (1998) Anaerobic digestion of swine manure: inhabition by ammonia. Water res 32: 5-12.

20. Niu Q, Qiao W, Qiang H, Hojo TYY (2013) Mesophilic methane fermentation of chicken manure at a wide range of ammonia concentration; Stability and recovery. Bioresources Technol 137: 358-367.

21. Agarwal A, Sexena M (2011) Assessment of pollution by physicochemical parameters using regression analysis: A case study of Gagan River at Moradabad-India. Adv Appl Sci Res 2: 185-189.

22. Kumar N, Sinha DK (2010) Drinking water quality management through correlation studies among various physicochemical parameters: a case study. Int J Environ Sci 1: 253-259.

23. Mulla JG, Farooqui M, Zaheer A (2007) A correlation and regression equations among water quality parameters. Int J Chem Sci 5: 943-952.

24. Chen Y, Cheng JJ, Creamer KS (2008) Inhibition of anaerobic digestion process: A review. Bioresource technology 99: 4044-4064. 